\title{
TRIBAL COMMUNITY AND DISASTER RESILIENCE: BAJO COMMUNITY AND THEIR COPING STRATEGY TO CYCLONE IN MUNA BARAT DISTRICT
}

\author{
*Dina Ruslanjari and Anisa Eka Puspitasari \\ Master Program in Disaster Management, \\ The Graduate School of Universitas Gadjah Mada
}

\author{
Titis Puspita Dewi \\ Extension and Communication Development, \\ The Graduate School, Universitas Gadjah Mada, Yogyakarta \\ Submitted:13-11-2018; Revised:03-05-2019; Accepred: 03-05-2019
}

\begin{abstract}
ABSTRAK
Kabupaten Muna Barat merupakan sebuah daerah rawan bencana alam, seperti angin puting beliung dan gelombang pasang. Angin puting beliung dan gelombang pasang sering terjadi dan kedua fenomena tersebut terjadi selama musim transisi (dari musim kemarau ke musim hujan). Penelitian ini bertujuan untuk menganalisis tingkat kerentanan dan kapasitas terkait kesiapan masyarakat Suku Bajo dalam menghadapi bencana angin puting beliung. Metode yang digunakan dalam penelitian ini adalah kuantitatif deskriptif. Selanjutnya, desa yang diteliti dipilih secara purposive, yaitu desa-desa yang terletak di laut dan terkena bencana angin puting beliung. Sampel yang dipilih adalah kepala keluarga Suku Bajo. Kerentanan dan kapasitas dihitung dengan pembobotan Analytical Hierarchy Process (AHP) dalam menentukan skala prioritas atau alternatif pilihan yang paling disukai. Hasil dari penelitian ini adalah Desa Tiga, Bero, Tasipi, dan Katela dikategorikan dalam kerentanan sedang serta Desa Mandike memiliki kerentanan rendah. Tingkat kapasitas masyarakat Desa Tiga, Bero, Tasipi, Mandike, dan Katela dikategorikan dalam kapasitas sedang.
\end{abstract}

Kata Kunci: Angin Puting Beliung; Kapasitas Masyarakat; Kerentanan Masyarakat.

\begin{abstract}
Muna Barat District is a prone area to natural disasters, such as cyclone and tidal waves. The cyclone and tidal waves often occur and those two phenomena occur during the transition season (from the dry to the rainy season). This research aims to analyze the vulnerability and capacity related to the readiness of the community of Bajo Tribe to face the cyclone. The method applied in this research is quantitative descriptive. Furthermore, the village that are selected purposively are those where located on the sea and hit by the cyclone. The sample chosen is the head of family of Bajo Tribe. Vulnerability and capacity were counted using Analytical Hierarchy Process (AHP) weighting in determining the priority scale or the most preferred alternative choice. The result of this research is Tiga, Bero, Tasipi, and Katela Village
\end{abstract}

*Corresponding author: dienarus@ugm.ac.id.

THE AUTHOR(S).This article is distributed under a Creative Commons Attribution-Share Alike 4.0 International license. Jurnal Kawistara is published by the Graduate School of Universitas Gadjah Mada. 
are categorized have medium vulnerability and Mandike Village has low vulnerability. Tiga, Bero, Tasipi, Mandike, and Katela Village are classified as medium community capacity.

Keywords: Community Capacity; Community Vulnerability; Cyclone.

\section{INTRODUCTION}

Disaster risk reduction in Indonesia begins at the birth of Law Number 24 of 2007 concerning Disaster Management which has developed until the recent time. The Sendai Framework for Disaster Risk Reduction in 2015-2030 was prepared to succeed the Hyogo Framework (2005-2015). The Sendai Framework defines "greatly reducing disaster risk and loss of life, livelihoods and health, and loss of economical, physical, social, environmental and cultural assets owned by individuals, business enterprises, communities and countries" (UNISDR, 2015). In line with the global paradigm, the 2015-2019 Medium Term Development Plan (RPJMN) of the Republic of Indonesia include disaster risk reduction in the sustainability development framework. Disaster risk reduction is a shared responsibility between the government (central and regional), relevant ministries, partners, and stakeholders. The central and regional governments are obliged and responsible in organizing disaster management, so that each region in disaster management efforts must have disaster management plans and regional action plan documents.

Based on the objectives target of the Sendai Framework for Disaster Risk Reduction (SFDRR), planning and controlling the potential risks is integrated by increasing capacity, reducing vulnerability, increasing resilience, and improving the preparedness of all stakeholders (UNISDR, 2015; BNPB, 2015). According to UNISDR (2009), disaster risk reduction is a conceptual framework of elements that contain the possibility of reducing disaster vulnerability, preventing, mitigating and increasing preparedness efforts from disaster impacts and threats for sustainable development.
In disaster risk reduction, community capacity has a very important role. The low capacity of the community will also reduce disaster risk reduction. It will give an impact on the many casualties when a disaster occurs. Likewise, vulnerability greatly influences people's safety from the threat of disaster. Vulnerability in disaster is strongly influenced preparedness (Paul, 2013). Muna Barat District is a prone area to natural disasters, such as earthquakes and tidal waves. The cyclone may appear during the day to night. A cyclone can be defined as a wind that suddenly occurs, it has a centre, moves around like a spiral and hits the Earth surface. The existence of a cyclone is very short, which is only about 3-5 minutes starting the first time it appears until it passes away, moreover the wind disaster caused by natural factors (Harsa, et al., 2011).

The cyclone is known as tambosisi (local language). The people of Muna Barat District know the cyclone as a disaster since 2015. Information from one of the employees of BPBD Muna Barat, the cyclone that occurred on 2015 was the biggest wind disaster as it gave the impact of 600 houses were severely damaged where it spread out within 3 subdistricts namely North Tiworo Sub-District, South Tiworo Sub-District, and Tiworo Island Sub-District. The incident was due to the location of those three sub-districts on the floating sea, far away from the main island, Muna.

A cyclone returned in February 2016 causing 234 houses to be severely damaged or slightly damaged. According to the results of cyclone and tidal wave survey, it is very common in the islands (Bero, Santigi, Tiga, Mandike, Katela, and Tasipi Village) from October to March, the people know these months as west season. In this season the condition of the community is not only affected by the threat of cyclones but also faces the threat of tidal waves that reaching 2 up to 3 meters so that they can't go to the sea in searching of fish. The condition of vulnerable communities with low community capacity, making the disaster has a high risk. A 
cyclone will give the result of house destruction and property. Nevertheless, cyclones and tidal waves disasters threaten their daily lives. From the introduction, the questions asked are as follows: "What is the capacity and vulnerability level of the community in dealing with the cyclone disaster preparedness?" The goals of this study are following to explore and analyses the community vulnerability and capacity of Bajo Tribe towards the cyclone hazard and to analyse the level of vulnerability and capacity that are to affected the community preparedness. It is expected that the results of the research can be an academic study of the policies of the regional government, especially the BPBD in the postrehabilitation program for the reconstruction of disaster impacts on the community.

The study of vulnerability and capacity needs to be done especially based on pre-research found high physical vulnerability that occurs in the community when a tornado disaster. Some literature is related to vulnerability and capacity studies, in a study by Suprapto, et al (2016), with the title "Analysis of Coastal Physical Vulnerability in the South Garut of West Java", conducted in 4 subdistricts namely Mekarmukti, Pakenjeng, Cikelet and Pameungpeuk Sub-Districts. The results of the research from the four sub-districts found that the medium vulnerability was $62.25 \%$, low category $28.42 \%$, and high level of vulnerability $9.33 \%$. Pameungpeuk Sub-District is an area with high vulnerability, precisely in the coastal tourism area of Santolo Garut, the area is a tourism location that is visited by tourists. Human activity in the region is very high, besides that there is a fairly high change in land use.

Research by Jaswadi, et al (2012) with the title "Level of Vulnerability and Capacity of Communities in Facing Flood Risk in Pasar Kliwon Sub-District, Surakarta City". This research is quantitative research. The results of the analysis showed that households with low levels of social vulnerability are $17 \%$, moderate vulnerability $66 \%$ and high vulnerability $17 \%$. Based on the physical vulnerability of the building, type 6 building, floored-cement with plywood walls, is the most vulnerable type of building. Type 4 and 5 buildings, walled tiles cement with floors cement, are the types of buildings that are not vulnerable. The level of capacity and perception of the community are all classified as medium. The results are conducted from those areas that located in high, medium, and low of disaster-prone area as well as the area with no vulnerability to the disaster.

Stimers MJ and Paul BK (2016) in their research titled "Toward Development of the Tornado Impact-Community Vulnerability Index", found that vulnerability in pre-disaster is influenced by age, race, income, gender, infrastructure, building density, environment and health. The behaviour of citizens in the community, the quality of construction protection, and the effectiveness of the warning system also affect vulnerability. The purpose of this study was to develop the Tornado Impact Community Vulnerability Index (TICV) which uses variables such as the number of people killed, economic impacts, and social vulnerability to describe the level of impact of cyclone in the community.

Walch (2017) in his research entitled “Typhoon Haiyan: encourages the limitation of resilience? Effect of inequality on disaster resilience and risk reduction policies in the Philippines". He explained that the number of victims was around 6,000 deaths and affected the lives of 14 million people. It is because in addition to the size of the cyclone, it was also influenced by corruption, the implementation, also the social economic inequality of the community. Moreover, this paper focuses on increasing social and economic inequality. The national level framework is not translated into programs that help lift people out of poverty, especially landless people. The country-led resilience policy focuses on the technical aspects of recovery rather than the root causes of vulnerability, explaining to a certain extent the high level of casualties after Haiyan typhoon. In this study, it does not depend on calculating the threat of tornado, but to analyse the vulnerabilities and capacities, which are very important in influencing 
disaster risk reduction actions, by reducing their vulnerability and increasing community capacity.

Vulnerability does not occur naturally but is related to the human dimension of disaster which is the result of the linkages of economic, social, cultural, institutional factors, politics that contributing to human life and the environment in which they live as Twigg (2004) stated. Vulnerability always changes dynamically every time (Thywissen, 2006) depends on the condition of the community's vulnerability to certain hazards.

UNISDR (2004) divides vulnerabilities into four types namely physical, social, economic and environmental. Each type of vulnerability from one another has related characteristics, whether it comes from physical, social, economic, and environmental factors. The level of vulnerability as one of the factors that influence the occurrence of a disaster, because a new disaster will occur if the danger exists in vulnerable conditions. According to Vogel and O'Brien (2004); Lummen and Yamada, (2014), vulnerability has multidimensional aspects (such as: physical, social, economic, environmental, institutional and human factors determining vulnerability); vulnerability can be measured at the level of individuals, households, communities to the state level; because each location requires its own approach. Vulnerability is related to risk elements (elements at risk), which include all objects; people, animals, activities and processes that can be adversely affected by harmful phenomena in certain areas, both directly or indirectly (Van Westen, et al, 2011). Physical vulnerability describes the physical condition that is vulnerable and potentially affected by certain hazard factors (Bakornas PB, 2007).

Social vulnerability shows its level to certain hazards (Bakornas PB, 2007). In vulnerable social conditions, it can be ascertained that it will cause a large loss if a disaster occurs. One concept of social vulnerability is that the limited ability of the community in facing natural disasters will give influence the resilience of society (Cutter et al., 2003; Siagian et al., 2012). Social vulnerability is a measure that is related to population sensitivity factors and the ability factors possessed in responding to and resilient from the impacts of natural disasters (Cutter and Finch, 2008; Aliabadi et al., 2015).

Economic vulnerability is identical to poverty, economic vulnerability, less of mutual reinforcing and it happens because of the same process. All poor people are vulnerable, but not all vulnerable people are poor. Economic vulnerability describes a condition of the level of economic fragility in the face of certain hazards (Bakornas PB, 2007). UNISDR (2004); Thywissen (2006) formulates a capacity that is a combination of a set of strengths, and resources available from a community, which can reduce the level of disaster risk. Capacity is understood as the ability of individuals or communities to reduce the impact of disasters, with the existence of awareness and preparedness (Jimee et al., 2006). Community awareness of disasters is defined as knowledge of preparedness for the community to reduce the risk of disaster. Community awareness of disasters can be viewed as knowledge, perceptions, community responses to disaster information (Jimee, 2006). A person's knowledge is influenced by socioeconomic factors, culture which includes religion, education and person's experience (Notoatmodjo, 2007). Disaster response is the relationship between emergency planners and emergency or disaster managers (Alexander, 2015). By knowing the vulnerability and capacity of the community, disaster risk is expected to be reduced, one of which is in the case of a cyclone disaster.

This research applies quantitative research. Data collection method in this study is a sampling research method where the research conducted by examining some members of the population that aims to determine the overall character of the population ( $\mathrm{Yu}$ nus, 2010). The population in this study is the number of household heads (KK) in each village. The population in each village from BPS (2014) can be seen in Table 1. 
Table 1.

The Population of Each Village on Tiworo Sub-District

\begin{tabular}{llll}
\hline No & Village & Household Head & Sample \\
\hline 1. & Tiga & 267 & 15 \\
\hline 2. & Bero & 116 & 7 \\
\hline 3. & Mandike & 249 & 14 \\
\hline 4. & Tasipi & 451 & 26 \\
\hline 5. & Katela & 244 & 32 \\
\hline \multicolumn{2}{l}{ Total } & 1.327 & 94 \\
\hline
\end{tabular}

Source: Data Analysis (2018)

The sample unit in this study is the head of the family (KK) which are the father (husband) or the mother (wife) who acts as the head of the family that has been left by the husband or their husband was died. Determination of the number of samples uses a determining table from the number of samples of population. This method is developed by Issac and Michael (Sugiyono, 2014). Based on the Table 1, the population (N) $=1.327$ with an error level of $10 \%$, the number of samples (S) is 94 samples. Moreover, the calculation of the number of samples in each village as the sub-population is conducted proportionally with carrying out the formula citied from Soepono (2002). The determination of respondent is firstly applied by sorting the head of family (KK) list, then it is filtered based on the sequence of sampling interval. The calculation of long interval sampling resulted 22 in each village (Malthuf, 2015).

Data collection techniques used in this study include field observations, questionnaires and structured interviews. The three data retrieval techniques are carried out by complementing one another in order to obtain the data that chosen by the researchers. The variables used in this study are presented in Table 2.

Table 2.

Research Variable

\begin{tabular}{|c|c|c|c|c|}
\hline No & Research Analysis & Component & Variable & $\begin{array}{l}\text { Data } \\
\text { Type }\end{array}$ \\
\hline \multirow[t]{13}{*}{1.} & \multirow{13}{*}{$\begin{array}{l}\text { Community } \\
\text { Vulnerability } \\
\text { Analysis Towards } \\
\text { Earthquake }\end{array}$} & \multirow{10}{*}{$\begin{array}{l}\text { Physical } \\
\text { Vulnerability }\end{array}$} & Building Wall Material & Nominal \\
\hline & & & Age of Building & Ratio \\
\hline & & & Building Structure & Nominal \\
\hline & & & Domicile Period & Ratio \\
\hline & & & Education Level & Ordinal \\
\hline & & & Number of Family Members & Ratio \\
\hline & & & Number of Disabilities & Ratio \\
\hline & & & Number of Dependents of Vulnerable Ages & Ratio \\
\hline & & & Number of Female & Ratio \\
\hline & & & Population Density & Interval \\
\hline & & \multirow{3}{*}{$\begin{array}{l}\text { Economic } \\
\text { Vulnerability }\end{array}$} & Type of Work & Nominal \\
\hline & & & Amount of Family Income & Ratio \\
\hline & & & Building Ownership & Nominal \\
\hline \multirow[t]{7}{*}{2.} & \multirow{7}{*}{$\begin{array}{l}\text { Community } \\
\text { Capacity Analysis } \\
\text { Towards Earthquake }\end{array}$} & \multirow[t]{4}{*}{ Awareness } & Disaster Knowledge & Interval \\
\hline & & & Respond Towards Disaster & Interval \\
\hline & & & Disaster Perception & Interval \\
\hline & & & Disaster Information & Interval \\
\hline & & \multirow[t]{3}{*}{ Preparedness } & Readiness & Interval \\
\hline & & & Membership in Organization & Interval \\
\hline & & & Disaster Training & Interval \\
\hline
\end{tabular}

Source: Literature Review and Data Analysis (2018) 
The researcher compiled a vulnerability variable assessment questionnaire that was used as input in vulnerabilities and capacities variable. Each component of vulnerability and capacity is analysed by weighting, scoring, and classification. Weighting analysis is done by Analytical Hierarchy Process (AHP), a measurement method developed by Thomas L. Saaty through pairwise comparation, depending on expert judgment in determining the priority scale or the most preferred alternative choice based on rational perceptions of experts (Saaty, 2008). Disaster practitioners in West Muna were used as respondents in weighting vulnerability variables using the AHP method, namely: BPBD West Muna Regency, Head of Social and Transmigration Office, West Muna Regency, Head of Emergency and Logistics Division of BPBD West Muna, Head of Rehabilitation Division and Reconstruction of BPBD in West
Muna Regency, Head of BPBD Prevention and Preparedness in West Muna Regency.

\section{DISCUSSION Vulnerability}

The physical vulnerability of the community is the dependent variable obtained from 3 (three) independent variables. The independent variable consists of the age of the building, material and structure of the house. The age of house building in this study consisted of: low class vulnerability, which the age of the building ranging from 0 - 12 years; medium class vulnerability is the ranging from 13-24 years; and high-class vulnerability which includes the approximately of 25 years of the building age. The results of research analysis on physical vulnerability with weights derived from AHP analysis can be seen in Print Screen 1 (one).

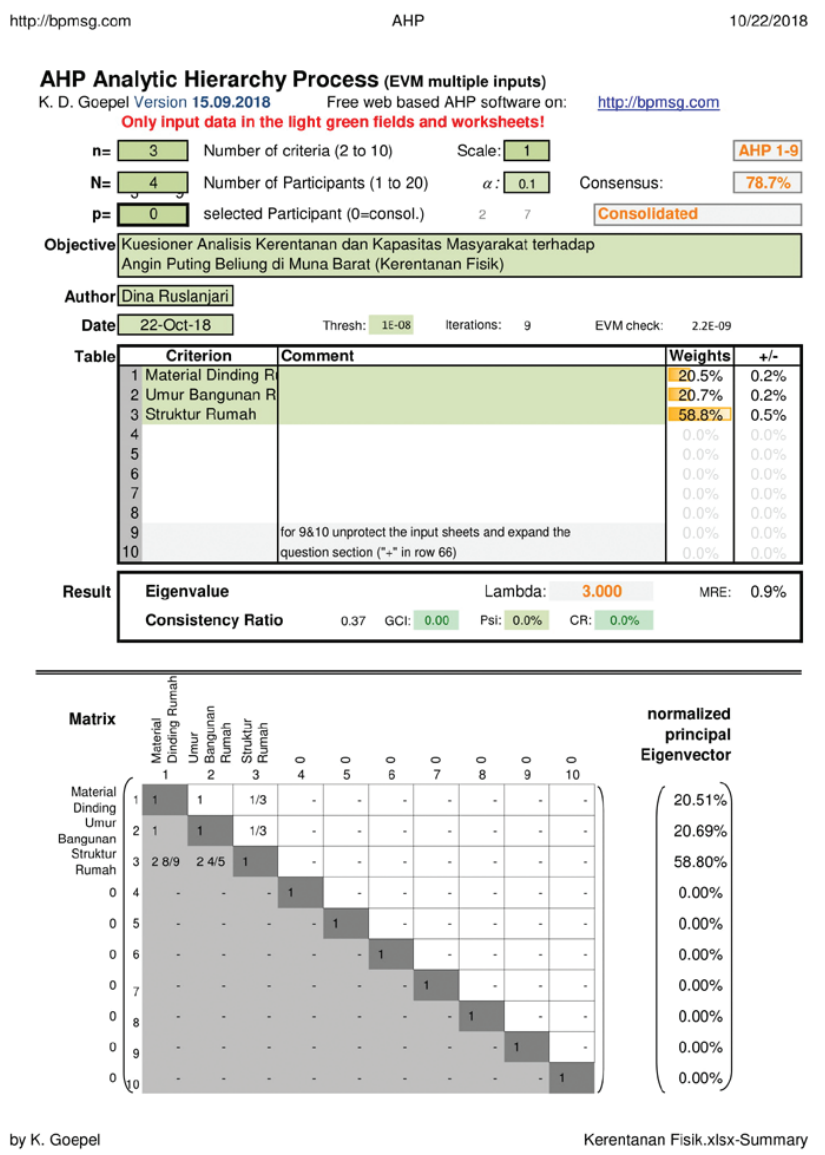

Figure 1.

Print Screen AHP

Source: Data Analysis (2018) 
Table 3.

Total Physical Vulnerability Classification

\begin{tabular}{lllllll}
\hline No. & Village & $\begin{array}{c}\text { The Age of Building } \\
(\mathbf{2 0 , 6 9 \% )}\end{array}$ & $\begin{array}{c}\text { Building Material } \\
\mathbf{( 2 0 , 5 1 \% )}\end{array}$ & $\begin{array}{c}\text { Material Structure } \\
\mathbf{( 5 8 , 8 0 \% )}\end{array}$ & Score & Classification \\
\hline 1 & Tiga & 3 & 3 & 3 & 3 & $\mathrm{H}$ \\
\hline 2 & Bero & 2 & 3 & 3 & 2,67 & $\mathrm{M}$ \\
\hline 3 & Mandike & 1 & 3 & 3 & 2,33 & $\mathrm{M}$ \\
\hline 4 & Tasipi & 3 & 3 & 3 & 3 & $\mathrm{H}$ \\
\hline 5 & Katela & 3 & 3 & 3 & 3 & $\mathrm{H}$ \\
\hline
\end{tabular}

Note: $\mathrm{H}=$ High (with scale 3 ), $M=$ Medium (with scale 2), $L=$ Low (with scale 1)

Source: Primer Data Analysis (2018)

Bakornas PB (2007) divided physical vulnerability into basic infrastructure, construction, and buildings. Traditional house of Bajo Tribe is square or rectangular. The roof is shaped like a pyramid which formed by thatch or zinc. The walls and floors of the house are made of wooden planks but there are still many Bajo houses that use silar leaves, the sago nan palm fronds as a wall.

Bajo tribal houses are made similar with a stage, the main material being figure 2 .

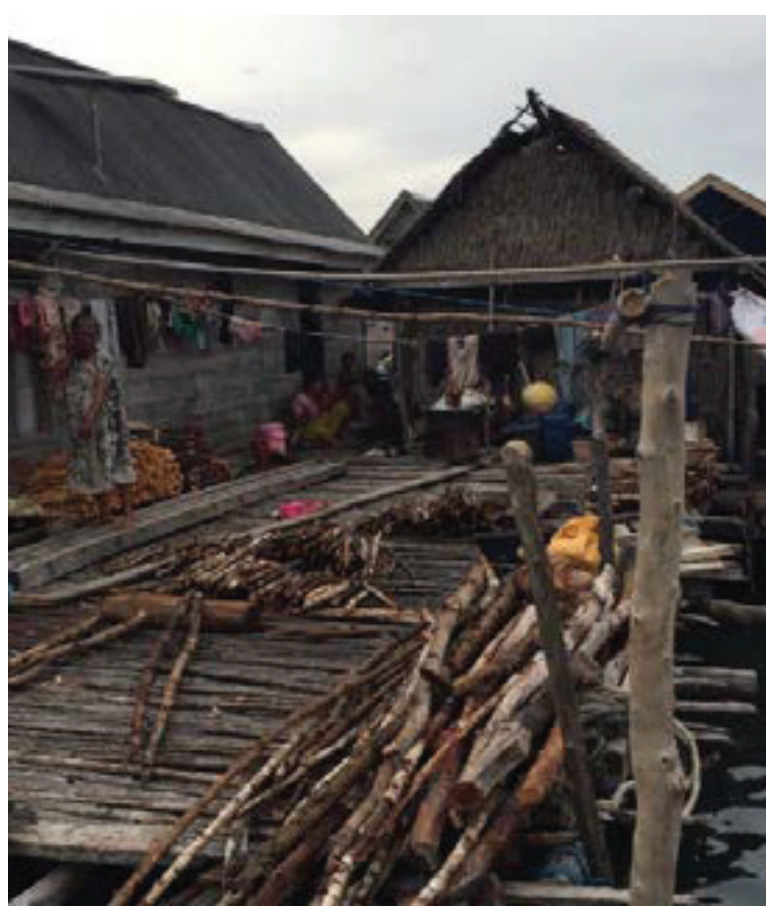

Figure 2.

Traditional Bajo Tribe Houses Prone to Cyclone Source: Researchers (2018) used is wood as the foundation and the body of the house. They use local wood such as ironwood, gravel, togoulu, kalakka and manjarite, which are round formed that still has skin, measuring between $15-25 \mathrm{~cm}$ in diameter. The longer the life of the building, the more vulnerable it will be, because the wood material will be weathered

Building material comes from wood, which certainly has a high vulnerability from the threat of a cyclone. Wood material is light as when it is exposed to wind with a speed of 40-50 km/hour and a very short duration, a maximum of 5 minutes, but it will have the effect of flying a house for the building that does not have strong structure (Harsa, et al, 2011).

The structure of the house building is the highest factor of physical vulnerability. Structure is the parts that make up the buildings such as foundations, sloop, walls, columns, rings, trestles, and roofs. The role of the building structure is to hold on the building load from the upper part of the building to the lower part of the building, then spread it to the ground, so that it can bear the gravity and building loads (https://blog-mue. blogspot.com/2016/03/definisi-strukturdan-kontruksi.html, retrieved on October 22, 2018). 

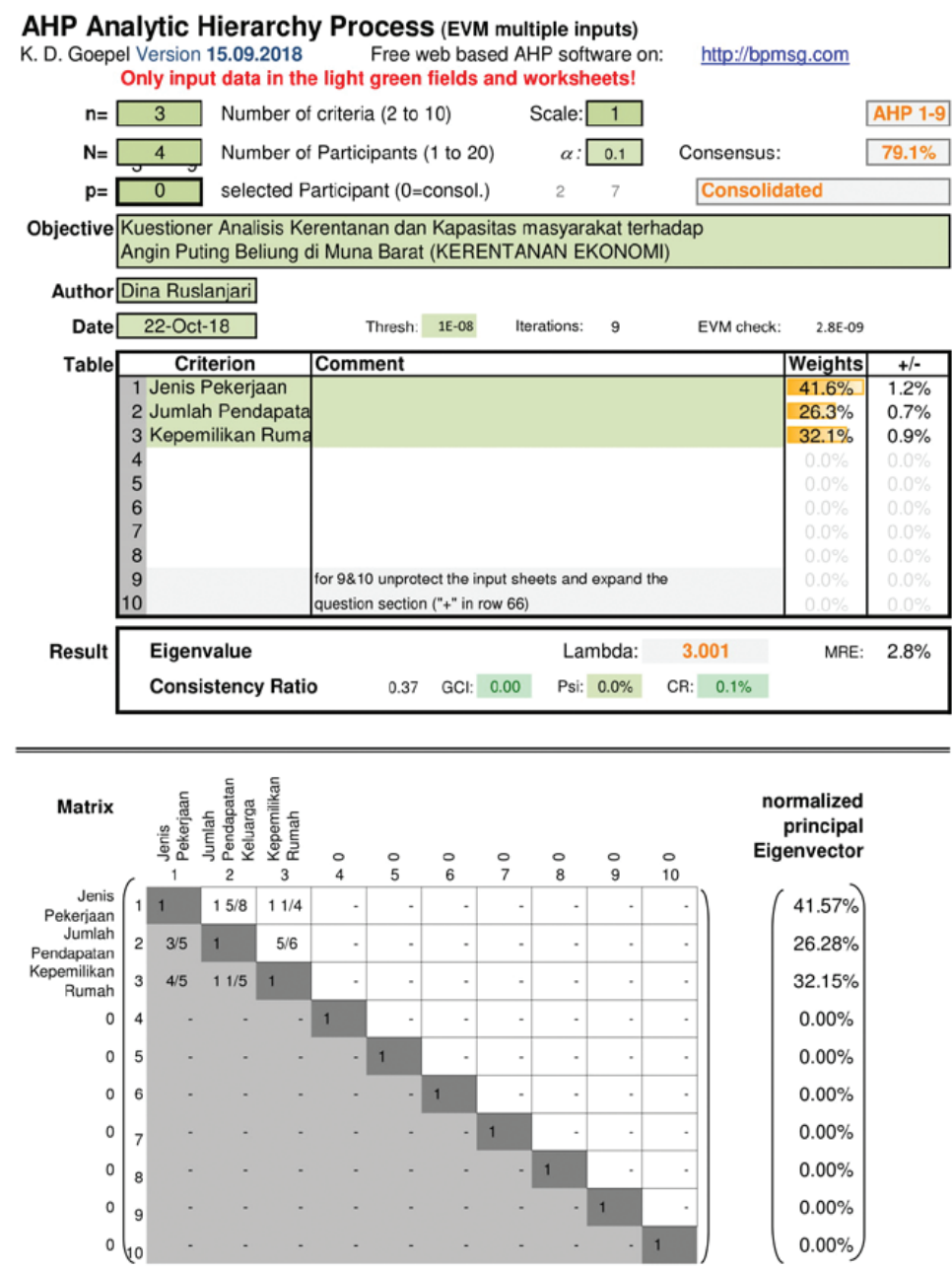

Figure 3.

Print Screen AHP

Source: Data Analysis (2018)

Table 4.

Total Economic Vulnerability Classification

\begin{tabular}{lllllll}
\hline No. & Village & $\begin{array}{c}\text { Type of Job } \\
(\mathbf{4 1 , 5 7 \% )}\end{array}$ & $\begin{array}{c}\text { Family Income } \\
\mathbf{( 2 6 , 2 8 )}\end{array}$ & $\begin{array}{c}\text { Building Ownership } \\
\mathbf{( 3 2 , 1 5 \% )}\end{array}$ & Score & Classification \\
\hline $\mathbf{1}$ & Tiga & 2 & 3 & 1 & 2 & $\mathrm{M}$ \\
\hline $\mathbf{2}$ & Bero & 2 & 3 & 1 & 2 & $\mathrm{M}$ \\
\hline $\mathbf{3}$ & Mandike & 2 & 2 & 1 & 1,67 & $\mathrm{~L}$ \\
\hline $\mathbf{4}$ & Tasipi & 2 & 3 & 1 & 2 & $\mathrm{M}$ \\
\hline $\mathbf{5}$ & Katela & 2 & 3 & 1 & 2 & $\mathrm{M}$ \\
\hline
\end{tabular}

Note: $H=$ High (with scale 3), $M=$ Medium (with scale 2), $L=$ Low (with scale 1)

Source: Primer Data Analysis (2018) 
Bakornas PB, (2007) stated that one vulnerability factor is economic vulnerability, which consists of work, house ownership, and family income. The average income of the community is low which is under $\mathrm{Rp} 1,450,000$ / month. The local fishermen only depend on the traditional equipment for fishing such as nets and a tool similar with narrow.

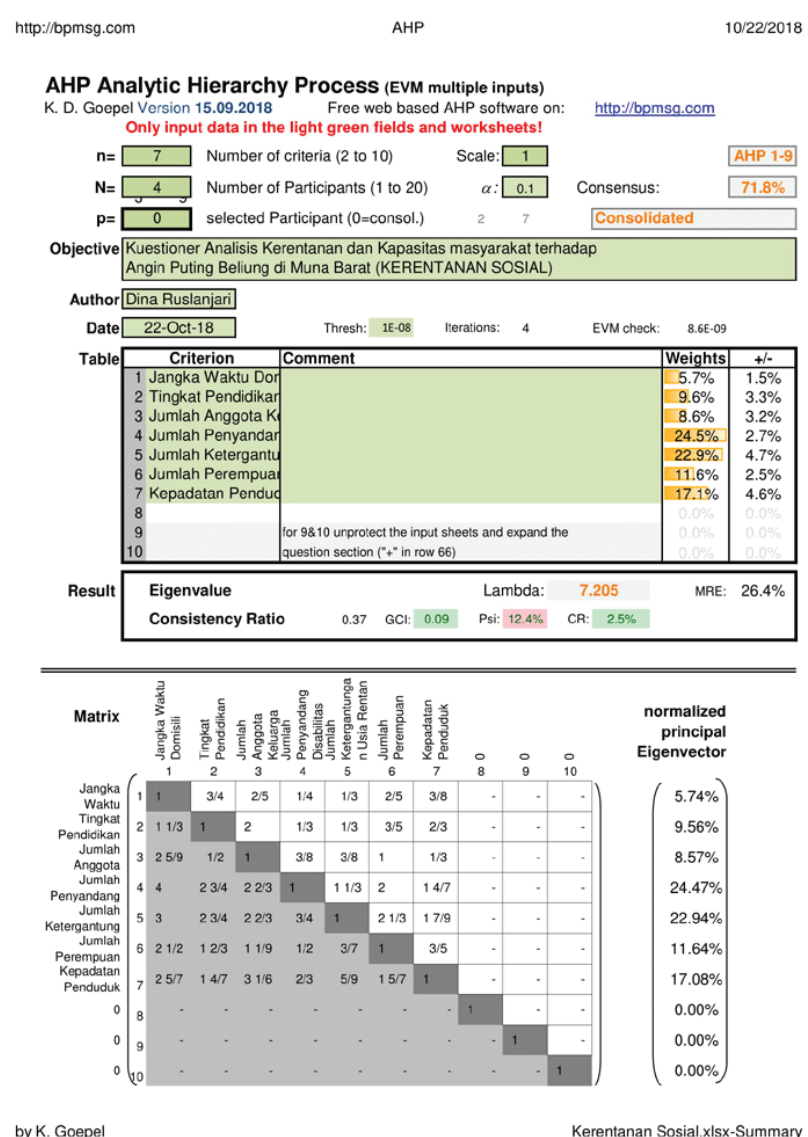

Figure 4.

Print Screen AHP

Source: Data Analysis (2018)

Tabel 5.

Total Social Vulnerability Classification

\begin{tabular}{|c|c|c|c|c|c|c|c|c|c|c|}
\hline No. & Village & 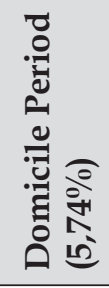 & 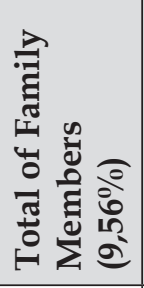 & 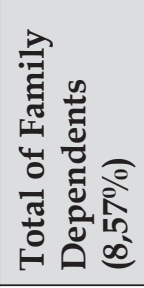 & 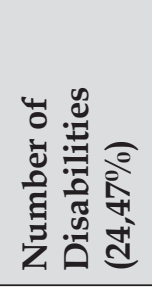 & 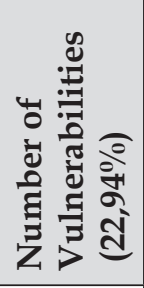 & 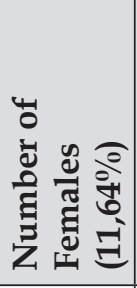 & 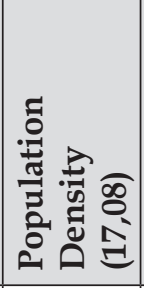 & ڤँ & : \\
\hline 1 & Tiga & 3 & 3 & 2 & 1 & 1 & 2 & 2 & 1,86 & $\mathrm{~L}$ \\
\hline 2 & Bero & 3 & 3 & 3 & 1 & 1 & 2 & 2 & 2 & $\mathrm{M}$ \\
\hline 3 & Mandike & 3 & 3 & 2 & 1 & 1 & 1 & 2 & 1,71 & $\mathrm{~L}$ \\
\hline 4 & Tasipi & 3 & 3 & 3 & 1 & 1 & 2 & 2 & 1,86 & $\mathrm{~L}$ \\
\hline 5 & Katela & 3 & 3 & 2 & 1 & 1 & 2 & 2 & 1,86 & $\mathrm{~L}$ \\
\hline
\end{tabular}

Note: $\mathrm{H}=$ High (with scale 3 ), $M=$ Medium (with scale 2 ), $\mathrm{L}=$ Low (with scale 1 )

Source: Data Analysis (2018) 
There are disabilities at Mandike Village and Tasipi Village. It happens because they dive to catch the fish in the night with only using flashlight and no safety equipment. It gives the impact their hands and foot are attacked by the sharks.

The number of disabilities is the highest factor in social vulnerability, although there are no disabled people from the research sample tested. The women on the islands are not many who can help her husband job because they take care of their children while some of them create nets. The rest of them peel the fish, take out the fish bone, and dry fish. The number of population density in a region determines the vulnerability condition, if a disaster occurs, because it is related to the number of fatalities.

Table 6.

Classification of Economic Vulnerability

\begin{tabular}{l|l|l|l|l|l|l}
\hline No. & \multicolumn{1}{|c|}{ Village } & $\begin{array}{c}\text { Type of Work } \\
\mathbf{( 4 1 , 5 7 \% )}\end{array}$ & $\begin{array}{c}\text { House Ownership } \\
\mathbf{( 3 2 , 1 5 \% )}\end{array}$ & $\begin{array}{l}\text { Income Average } \\
\mathbf{( 2 6 , 2 8} \mathbf{0})\end{array}$ & Score & Class \\
\hline $\mathbf{1 .}$ & Tiga & 2 & 1 & 3 & 2 & $\mathrm{M}$ \\
\hline $\mathbf{2 .}$ & Bero & 2 & 1 & 3 & 2 & $\mathrm{M}$ \\
\hline $\mathbf{3 .}$ & Mandike & 2 & 1 & 2 & 1,67 & $\mathrm{~L}$ \\
\hline $\mathbf{4 .}$ & Tasipi & 2 & 1 & 3 & 2 & $\mathrm{M}$ \\
\hline $\mathbf{5 .}$ & Katela & 2 & 1 & 3 & 2 & $\mathrm{M}$ \\
\hline
\end{tabular}

Note: $H=$ High (with scale 3 ), $M=$ Medium (with scale 2), $L=$ Low (with scale 1)

Source: Data Analysis (2018)

The type of community work is fishermen and they have their own wooden boats, even though the boats are very simple. The boat is also used for the transportation to other villages or to the main island in the city of Muna Barat Regency. In addition, children go to schools that located on the other islands by boat. The house is self-owned with the exiguous condition which can be possibility destroyed when big cyclone happens.

Total vulnerability is the combination of physical, economic and social vulnerabilities that can be seen in Table 7. This study does not calculate environmental vulnerability, due to its definition based on UNISDR, 2004. Environmental vulnerability is measured by access to health facilities, road networks and availability of clean water. These three variables have the same results, which have all high vulnerabilities. This result is based on the unavailability of road networks where there is only the wooden bridge that connects one house to another, the lack of clean water so that people must buy, and there is no access to health facilities.

Table 7.

Total of Vulnerability Score

\begin{tabular}{l|l|l|l|l|l}
\hline No. & \multicolumn{1}{|c|}{ Village } & \multicolumn{1}{|c|}{$\begin{array}{c}\text { Physical } \\
\text { Vulnerability }\end{array}$} & $\begin{array}{c}\text { Social } \\
\text { Vulnerability }\end{array}$ & \multicolumn{1}{|c}{$\begin{array}{c}\text { Economic } \\
\text { Vulnerability }\end{array}$} & $\begin{array}{c}\text { Average Score of } \\
\text { Vulnerability }\end{array}$ \\
\hline 1. & Tiga & $\mathrm{H}(3)$ & $\mathrm{L}(1)$ & $\mathrm{M}(2)$ & 2 \\
\hline 2. & Bero & $\mathrm{M}(2)$ & $\mathrm{M}(2)$ & $\mathrm{M}(2)$ & 2 \\
\hline 3. & Mandike & $\mathrm{M}(2)$ & $\mathrm{L}(1)$ & $\mathrm{L}(1)$ & 1,33 \\
\hline 4. & Tasipi & $\mathrm{H}(3)$ & $\mathrm{L}(1)$ & $\mathrm{M}(2)$ & 2 \\
\hline 5. & Katela & $\mathrm{H}(3)$ & $\mathrm{L}(1)$ & $\mathrm{M}(2)$ & 2 \\
\hline
\end{tabular}

Note: $\mathrm{H}=$ High (with scale 3 ), $M=$ Medium (with scale 2), $\mathrm{L}=$ Low (with scale 1)

Source: Data Analysis (2018) 


\section{Community Capacity}

The level of community capacity is carried out from awareness assessment variables consisting of knowledge indicators, responses to the cyclone, perception and information. Preparedness assessment variables consisting of preparation before the occurrence of a cyclone, membership in community organizations, and participation in disaster training. Community capacity analysis is implemented to obtain a total capacity index value which is the sum of awareness and preparedness indices.

Awareness assessment variables in this study consisted of: knowledge indicators, responses to the cyclones, perceptions and information made in several questions with answer choices No (1) - showing low awareness; Hesitate (2) - providing moderate awareness; and Yes (3) - presenting high awareness. The results of the research questionnaire analysis on the variables of awareness assessment can be seen in Table 8 .

Table 8.

Variable of Awareness Assesment

\begin{tabular}{|c|c|c|c|c|c|}
\hline No. & Village & Knowledge & Response & Perception & Information \\
\hline 1. & Tiga Village & $\begin{array}{l}\text { Low - } 1 \text { (do not } \\
\text { have enough } \\
\text { knowledge about } \\
\text { cyclone disasters) }\end{array}$ & $\begin{array}{l}\text { High - } 3 \\
\text { (conducting } \\
\text { some responses } \\
\text { while the } \\
\text { cyclone occurs) }\end{array}$ & $\begin{array}{l}\text { High - } 3 \text { (have } \\
\text { perception } \\
\text { toward cyclone } \\
\text { disaster) }\end{array}$ & $\begin{array}{l}\text { Low - } 1 \text { (The } \\
\text { unavailability } \\
\text { of cyclone } \\
\text { information) }\end{array}$ \\
\hline 2. & Bero Village & $\begin{array}{l}\text { Low - } 1 \text { (do not } \\
\text { have enough } \\
\text { knowledge about } \\
\text { cyclone disasters) }\end{array}$ & $\begin{array}{l}\text { High - } 3 \\
\text { conducting } \\
\text { some responses } \\
\text { while the } \\
\text { cyclone occurs) }\end{array}$ & $\begin{array}{l}\text { High - } 3 \text { (have } \\
\text { perception } \\
\text { toward cyclone } \\
\text { disaster) }\end{array}$ & $\begin{array}{l}\text { Low - } 1 \text { (The } \\
\text { unavailability } \\
\text { of cyclone } \\
\text { information) }\end{array}$ \\
\hline 3. & Mandike Village & $\begin{array}{l}\text { Low - } 1 \text { (do not } \\
\text { have enough } \\
\text { knowledge about } \\
\text { cyclone disasters) }\end{array}$ & $\begin{array}{l}\text { High - } 3 \\
\text { (conducting } \\
\text { some responses } \\
\text { while the } \\
\text { cyclone occurs) }\end{array}$ & $\begin{array}{l}\text { High - } 3 \text { (have } \\
\text { perception } \\
\text { toward cyclone } \\
\text { disaster) }\end{array}$ & $\begin{array}{l}\text { Low - } 1 \text { (The } \\
\text { unavailability } \\
\text { of cyclone } \\
\text { information) }\end{array}$ \\
\hline 4. & Tasipi Village & $\begin{array}{l}\text { Low - } 1 \text { (do not } \\
\text { have enough } \\
\text { knowledge about } \\
\text { cyclone disasters) }\end{array}$ & $\begin{array}{l}\text { High - } 3 \\
\text { (conducting } \\
\text { some responses } \\
\text { while the } \\
\text { cyclone occurs) }\end{array}$ & $\begin{array}{l}\text { High - } 3 \text { (have } \\
\text { perception } \\
\text { toward cyclone } \\
\text { disaster) }\end{array}$ & $\begin{array}{l}\text { Low - } 1 \text { (The } \\
\text { unavailability } \\
\text { of cyclone } \\
\text { information) }\end{array}$ \\
\hline 5. & Katela Vilage & $\begin{array}{l}\text { Low - } 1 \text { (do not } \\
\text { have enough } \\
\text { knowledge about } \\
\text { cyclone disasters) }\end{array}$ & $\begin{array}{l}\text { High - } 3 \\
\text { (conducting } \\
\text { some responses } \\
\text { while the } \\
\text { cyclone occurs) }\end{array}$ & $\begin{array}{l}\text { High - } 3 \text { (have } \\
\text { perception } \\
\text { toward cyclone } \\
\text { disaster) }\end{array}$ & $\begin{array}{l}\text { Low - } 1 \text { (The } \\
\text { unavailability } \\
\text { of cyclone } \\
\text { information) }\end{array}$ \\
\hline
\end{tabular}

Note: $\mathrm{H}=$ High (with scale 3 ), $M=$ Medium (with scale 2), $\mathrm{L}=$ Low (with scale 1)

Source: Data Analysis (2018)

The results of the questionnaire related to community capacity variables have been analysed and then the arrangement of the capacity variable for assessment questionnaire which being applied as the input for weighting.
The researcher classifies the total awareness capacity based on the independent variables to form Table 9. The indicators include knowledge, responses, perception and information against cyclone. 
Table 9.

Classification of Total Awareness Capacity

\begin{tabular}{|c|c|c|c|c|c|c|c|}
\hline No. & Village & $\begin{array}{c}\text { Knowledge } \\
(31,67 \%)\end{array}$ & $\begin{array}{c}\text { Responses } \\
(14,75 \%)\end{array}$ & $\begin{array}{c}\text { Perception } \\
(19,72 \%)\end{array}$ & $\begin{array}{c}\text { Information } \\
(33,87 \%)\end{array}$ & Score & Class \\
\hline 1. & Tiga & 1 & 3 & 3 & 1 & 2 & $\mathrm{M}$ \\
\hline 2. & Bero & 1 & 3 & 3 & 1 & 2 & $\mathrm{M}$ \\
\hline 3. & Mandike & 1 & 3 & 3 & 1 & 2 & $\mathrm{M}$ \\
\hline 4. & Tasipi & 1 & 3 & 3 & 1 & 2 & $\mathrm{M}$ \\
\hline 5. & Katela & 1 & 3 & 3 & 1 & 2 & $\mathrm{M}$ \\
\hline
\end{tabular}

Source: Data Analysis (2018)

Note: $\mathrm{H}=$ High (with scale 3 ), $M=$ Medium (with scale 2), L = Low (with scale 1)

Preparedness assessment variables in this study consisting of: indicators of preparation before the occurrence of a cyclone, membership in community organizations, and participation in disaster training which made in several questions with the choice of answers No (1) - showing low preparedness; Doubt (2) - providing moderate prepared- ness; and Yes (3) - presenting high preparedness.

The results of the research questionnaire analysis on preparedness assessment variables can be seen in Table 10. The capacity of the community is carried out to obtain total capacity index value which is the sum of the awareness and preparedness index

Table 10.

Community Preparedness Assessment

\begin{tabular}{|c|c|c|c|c|}
\hline No. & Village & $\begin{array}{c}\text { Preparedness Before the } \\
\text { Cyclone Occurs }\end{array}$ & $\begin{array}{c}\text { Membership in Community } \\
\text { Organization }\end{array}$ & $\begin{array}{c}\text { Participation in } \\
\text { Disaster Training }\end{array}$ \\
\hline 1. & Tiga & $\begin{array}{l}\text { Low - } 1 \text { (No } \\
\text { preparedness before the } \\
\text { disaster happens) }\end{array}$ & $\begin{array}{l}\text { Medium - } 1 \text { (Not in a } \\
\text { Community Related to } \\
\text { Disaster) }\end{array}$ & $\begin{array}{l}\text { Low }-1 \text { (Not often } \\
\text { involved in disaster } \\
\text { training) }\end{array}$ \\
\hline 2. & Bero & $\begin{array}{l}\text { Low }-1 \text { (No } \\
\text { preparedness before the } \\
\text { disaster happens) }\end{array}$ & $\begin{array}{l}\text { Medium - } 1 \text { (Not in a } \\
\text { Community Related to } \\
\text { Disaster) }\end{array}$ & $\begin{array}{l}\text { Low }-1 \text { (Not often } \\
\text { involved in disaster } \\
\text { training) }\end{array}$ \\
\hline 3. & Mandike & $\begin{array}{l}\text { Low - } 1 \text { (No } \\
\text { preparedness before the } \\
\text { disaster happens) }\end{array}$ & $\begin{array}{l}\text { Medium - } 1 \text { (Not in a } \\
\text { Community Related to } \\
\text { Disaster) }\end{array}$ & $\begin{array}{l}\text { Low - } 1 \text { (Not often } \\
\text { involved in disaster } \\
\text { training) }\end{array}$ \\
\hline 4. & Tasipi & $\begin{array}{l}\text { Low - } 1 \text { (No } \\
\text { preparedness before the } \\
\text { disaster happens) }\end{array}$ & $\begin{array}{l}\text { Medium - } 1 \text { (Not in a } \\
\text { Community Related to } \\
\text { Disaster) }\end{array}$ & $\begin{array}{l}\text { Low - } 1 \text { (Not often } \\
\text { involved in disaster } \\
\text { training) }\end{array}$ \\
\hline 5. & Katela & $\begin{array}{l}\text { Low - } 1 \text { (No } \\
\text { preparedness before the } \\
\text { disaster happens) }\end{array}$ & $\begin{array}{l}\text { Medium - } 1 \text { (Not in a } \\
\text { Community Related to } \\
\text { Disaster) }\end{array}$ & $\begin{array}{l}\text { Low }-1 \text { (Not often } \\
\text { involved in disaster } \\
\text { training) }\end{array}$ \\
\hline
\end{tabular}

The sum of awareness and preparedness the namely is community capacity indicates is shown in Table 11. Source: Data Analysis (2018) 
Table 11.

Community Capacity

\begin{tabular}{lllllll}
\hline No. & Village & $\begin{array}{c}\text { Awareness } \\
\text { Assessment Variable }\end{array}$ & $\begin{array}{c}\text { Preparedness } \\
\text { Assessment Variable }\end{array}$ & $\begin{array}{c}\text { Total of } \\
\text { Assessment } \\
\text { Variable }\end{array}$ & $\begin{array}{c}\text { Average of } \\
\text { Community } \\
\text { Capacity }\end{array}$ \\
\hline 1. & Tiga & 2 & 1 & 3 & 1,5 \\
\hline 2. & Bero & 2 & 1 & 3 & 1,5 \\
\hline 3. & Mandike & 2 & 1 & 3 & 1,5 \\
\hline 4. & Tasipi & 2 & 1 & 3 & 1,5 \\
\hline 5. & Katela & 2 & 1 & 3 & 1,5 \\
\hline
\end{tabular}

Note: $\mathrm{H}=$ High, $\mathrm{M}=$ Medium, $\mathrm{L}=\mathrm{Low}$

Source: Data Analysis (2018)

Based on Table11. Typology of Community Vulnerability and Capacity in Cyclone Disaster
Preparedness (Muta'ali, 2014 modified by researchers), the researchers conclude the analysis of community preparedness in Table 12.

Table 12.

Total of Community Preparedness

\begin{tabular}{llll}
\hline No. & \multicolumn{1}{c}{ Village } & Vulnerability Average & Total Variable Average of Community Capacity \\
\hline 1. & Tiga & 2 & 1,5 \\
\hline 2. & Bero & 2 & 1,5 \\
\hline 3. & Mandike & 1,33 & 1,5 \\
\hline 4. & Tasipi & 2 & 1,5 \\
\hline 5. & Katela & 2 & 1,5 \\
\hline
\end{tabular}

Note: $\mathrm{H}=$ High, $\mathrm{M}=$ Medium, $\mathrm{L}=\mathrm{Low}$

Source: Data Analysis (2018)

Furthermore, the typology is made in Table 13 as the function combining the results of Table 11 and Table 12.

Table 13.

Typology of Community Vulnerability and Capacity

\begin{tabular}{llll}
\hline \multicolumn{1}{c}{ Community Typology } & Low Capacity & Medium Capacity & High Capacity \\
\hline High Vulnerability & 1 & 2 & 3 \\
\hline & & & \\
\hline Medium Vulnerability & 4 & $\begin{array}{l}\text { Tiga Village } \\
\text { Bero Village } \\
\text { Tasipi Village } \\
\text { Katela Village }\end{array}$ & 6 \\
\hline Low Vulnerability & 7 & Mandike Village & 9 \\
\hline
\end{tabular}

Source: Data Analysis (2018)

\section{CONCLUSION}

The results that have been conducted in this study show the villages in Muna Barat
District, consisting of 2 types as following: 1) Tiga, Bero, Tasipi, and Katela Village have medium vulnerability where Mandike Vil- 
lage has low vulnerability, 2) the villages of Tiga, Bero, Tasipi, Mandika, and Katela Village are classified as medium capacity level, and 3) typology of the community in Tiga, Bero, Tasipi, and Katela Village are medium in case of both capacity and vulnerability. However, Mandike Village is categorized as medium capacity and low vulnerability.

\section{RECOMMENDATION}

The condition of the community with a high level of vulnerability and low capacity needs to be conducted in training and awareness raising by the government and related organizations. The community needs to add insight into rehabilitation-reconstruction activities after cyclone with non-structural mitigation such as extension or socialization. This is done so that the damage and losses suffered by the community don't occur again in the next disaster

\section{REFERENCE}

Aliabadi, S., and Modiri. 2015. The Social and Physical Vulnerability Assessment of Old Texture Against Earthquake (Case Study: Fahadan District in Yazd City. Arab Journal GEOSCI, 8(12): 10775-10787.

Alexander, D. 2015. Disaster and Emergency Planning for Preparedness, Response, and Recovery. Retrieved at April 3, 2019. Available Online at http://oxfordre.com/ naturalhazardscience/view/10.1093/ acrefore/9780199389407.001.0001/ acrefore-9780199389407-e-12.

BAKORNASPB. 2007. Pengenalan Karakteristik Bencana dan Upaya Mitigasinya di Indonesia, Jakarta: Direktorat Mitigasi Badan Koordinasi Nasional Penanganan Bencana (BAKORNAS PB). Bakornas PB. Jakarta.

Badan Nasional Penanggulangan Bencana (BNPB). 2015. Rencana Nasional Penanggulangan Bencana. BNPB, Jakarta: Badan Nasional Penanggulangan Bencana.
Badan Pusat Statistik Kabupaten Muna. 2017. Muna Barat Dalam Angka. Badan Pusat Statistik Kabupaten Muna, Sawerigadi: Badan Pusat Statistik Kabupaten Muna.

Birkmann. 2006. Measuring Vulnerability to Promote Disaster-Resilient Societies: Conceptual Frameworks and Definitions, New York: United Nations University Press.

Cutter, S.L., Boruff, B.J., and Shirley, W.L. 2003. Social Vulnerability to Environmental Hazards. Social Science Quarterly, Southwestern Social Science Association, 84(2): 242-261.

Cutter, S.L. and Finch, C. 2008. Temporal and Spatial Changes in Social Vulnerability to Natural Hazards. Proceedings of the National Academy of Sciences, 105(1): 2301-2306.

Harsa, H., Handayani, R. K. S, and Noviati, W. 2011. Pemanfaatan Sataid untuk Analisa Banjir dan Angin Puting Beliung: Studi Kasus Jakarta dan Yogyakarta. Retrieved May 20, 2018. Available Online at puslitbang. bmkg.go.id/jmg/index.php/jmg/article/ view/101.

Jaswadi; Rijanta, R.; dan Hadi, M. P. 2012. Tingkat Kerentanan dan Kapasitas Masyarakat dalam Menghadapi Risiko Banjir di Kecamatan Pasar Kliwon Kota Surakarta. Majalah Geografi Indonesia, 26(2): 119-148.

Jimee, G.K. 2006. Seismic Vulnerability and Capacity Assessment at Ward Level A Case Study of Ward No. 20, Lalitpur Sub - Metropolitan City, Nepal. Thesis. Netherland: ITC Enschede.

Lummen and Yamada. 2014. Implementation of an Integrated Vulnerability and Risk Assessment Model. Nat Hazards, 73(1): 1085-1117.

Malthuf, Muhammad. 2015. Analisis Persepsi Risiko Bencana Gempabumi di Kabupaten Klaten, Provinsi Jawa 
Tengah. Pertemuan Ilmiah Tahunan Riset Kebencanaan Ke-2. Yogyakarta: Ikatan Ahli Bencana Indonesia (IABI).

MJ, Stimers and BK, Paul. 2016. Toward Development of the Tornado ImpactCommunity Vulnerability Index. Journal of Geography and Natural Disasters, 6(1): 1-11.

Muta'ali. Luthfi. 2014. Perencanaan Pengembangan Wilayah Berbasis Pengurangan Risiko Bencana. Yogyakarta: BPFG Universitas Gadjah Mada.

Notoatmodjo, S. 2007. Promosi Kesehatan dan Ilmu Perilaku. Jakarta: Rineka Cipta

Paul, Shitangsu Kumar. 2013. Vulnerability Concepts and Its Application in Various Fields: A Review on Geographical Perspective. Journal Life Earth Sci, 8(1): 63-81.

Peraturan Kepala Badan Nasional Penanggulangan Bencana Nomor 02 Tahun 2012 Tentang Pedoman Umum Pengkajian Risiko Bencana. Jakarta.

Ruslanjari, Dina. 2016. Pengaruh Sosio Kultural Kesiapsiagaan Masyarakat dalam Peningkatan Kapasitas Pasca Bencana Gempabumi (Kasus Kabupaten Alor - NTT). Yogyakarta: Prosiding Hibah SPs.

Saaty, T.L. 2008. Decision Making with The Analytic Hierarchy Process. International Journal Services Sciences, $1(1)$.

Sekretariat Kabinet Republik Indonesia. 2015. Presidential Decree No. 2 of 2015 on the National Medium-Term Development Plan (RPJMN) 20152019. Sekretariat Kabinet. Jakarta

Siagian, T.H, Purhadi, Suhartono, Ritonga, H. 2012. Social Vulnerability to Natural Hazards in Indonesia: Driving Factors and Policy Implications.
Nat Hazards, 70(1): 1603-1617. DOI 10.1007/s11069-013-0888-3.

Soepono, B. 2002. Statistik dalam Penelitian Ilmu-Ilmu Sosial dan Pendidikan. Jakarta: Rineka Cipta.

Sugiyono. 2014. Metode Penelitian Kuantitatif Kualitatif dan RED. Bandung: Alfabeta.

Suprapto, O., Harahap, S. A., and Herawati, T. 2016. Analisis Kerentanan Fisik Pantai di Pesisir Garut Selatan Jawa Barat. Jurnal Perikanan Kelautan, 7(2): 51-57.

Thywissen, 2006. Components of Risk, A Comparative Glossary. Bonn: United Nations University Institute for Environment and Human Security.

Twigg, J. 2004. Disaster Risk Reduction: Mitigation and Preparedness in Development and Emergency Programming, Humanitarian Practice Network (HPN), London: Good Practice Review 9.

Undang-Undang Republik Indonesia Nomor 24 Tahun 2007 Tentang Penanggulangan Bencana. Lembaran Negara Republik Indonesia Tahun 2007 Nomor 66. Jakarta: Sekretariat Kabinet.

UNISDR. 2004. Living with Risk: A Global Review of Disaster Reduction Initiatives. New York: United Nations International Strategy for Disaster Reduction Secretariat (UNISDR).

UNISDR. 2009. UNISDR Terminology on Disaster Risk Reduction. Geneva: United Nations International Sustainable Development Reduction (UNISDR).

UNISDR. 2015. Sendai Framework for Disaster Risk Reduction 20152030. Geneva: United Nations International Strategy for Disaster Reduction Secretariat (UNISDR).

Van Westen, C. J., Alkema, D., Damen, M. C., Kerle, N., and Kingma, N. C. 
2011. Multi-Hazard Risk Assessment. Netherlands: ITC.

Vogel, C. and O'Brien, K. 2004. Vulnerability and Global Environmental Change: Rhetoric and Reality. Information Bulletin on Global Environmental Change and Human Security, Number 13. Ottawa: Environmental Change and Security Project and the International Development Research Centre.
Walch, C.. 2017. Typhoon Haiyan: Pushing the Limits of Resilience? The Effect of Land Inequality on Resilience and Disaster Risk Reduction Policies in The Philippines. Journal Critical Asian Studies, 50(1): 122-135.

Yunus, H. S. 2010. Metodologi Penelitian Wilayah Kontemporer. Yogyakarta: Pustaka Pelajar. 